\title{
FUNERARY SYMBOLS ON THE TEMPLE DECORATIONS FROM THE TALAMONACCIO
}

\section{Albert Nijboer}

Part-time lecturer in Conservation and Material Science (1987) at the Department of Archaeology, State University of Groningen, the Netherlands. Institute of Archaeology, 1984-1987.

\section{Introduction}

Since the 15 th century AD Talamone, a village on a bay along the Tyrrhenian coast midway between Florence and Rome, has been associated with the Etruscan Telamon. The derivation Talamonaccio for the hill on the opposite side of the bay, has been documented since the 18th century. Telamon is mentioned twice in ancient historiography, once by Polybius (204-122 BC) who describes the battle against the Gauls in 225 BC (II, 23.531.7 ), and once by Pliny who, in the third quarter of the 1st century AD, describes the disembarcation in $87 \mathrm{BC}$ by Gaius Marius during the civil war (N.H., III, 51).

On the Talamonaccio,the famous 2 nd century BC terracotta, decorations depicting the battle of the Seven against Thebes (Fig.1) were found in the late 19th century. The battle of the Seven against Thebes was the final stage of the family tragedy of the Labdakides, the second royal dynasty of Thebes. Seven heroes Adrastus, Tydeus, Polyneices, Capaneus, Hippomedon, Parthenopaios and Amphiaraus went to Thebes to dislodge Eteocles, the brother of Polyneices, from the throne. Amphiaraus, a seer, knew that this battle would be fatal for all of them except Adrastus. Thus Capaneus died after he fell from a ladder while assaulting the walls of Thebes, seen on the upper level in the centre of the pediment (Fig. 1). Amphiaraus was swallowed by the earth while he flew from the battlefield, depicted in the left comer of the pediment. Adrastus, depicted on his chariot to the right of Capaneus, was saved from death by the speed of his horse Arion. The two brothers Polyneices and Eteocles who killed each other in front of the Theban walls are depicted, dying, with their father Oedipus and sister Iocaste on the lower level in the centre, underneath Capaneus. The other heroes Parthenopaios, Hippomedon andTydeus are not represented on the remains of the Talamonaccio pediment. The iconography of the pediment is well desribed by von Freytag gen. Löringhoff (1986).

Myths like that of the Seven against Thebes were depicted by the Etruscans from an early period. These myths might have been introduced, as a legend asserts, by the Corinthian artist Demaratus and other Greek artists who emigrated to Etruria in the 7th century BC A second source of knowledge of the Greek myths came from Southern Italy (Krauskopf 1974, 61). During the 5 th century BC the Etruscans developed a preference for certain mythological themes. Some of these themes like the death of Capaneus and Tydeus and the Seven against Thebes were hardly depicted in Greece. In the 4th century BC the fratricide of Eteocles and Polyneices was added to these preferred themes. In the 3rd and 2nd century BC however depictions of the battle of the Seven against Thebes and the fratricide were mainly used on artefacts connected with death such as cinerary ums and sarcophagi. The themes were therefore part of 


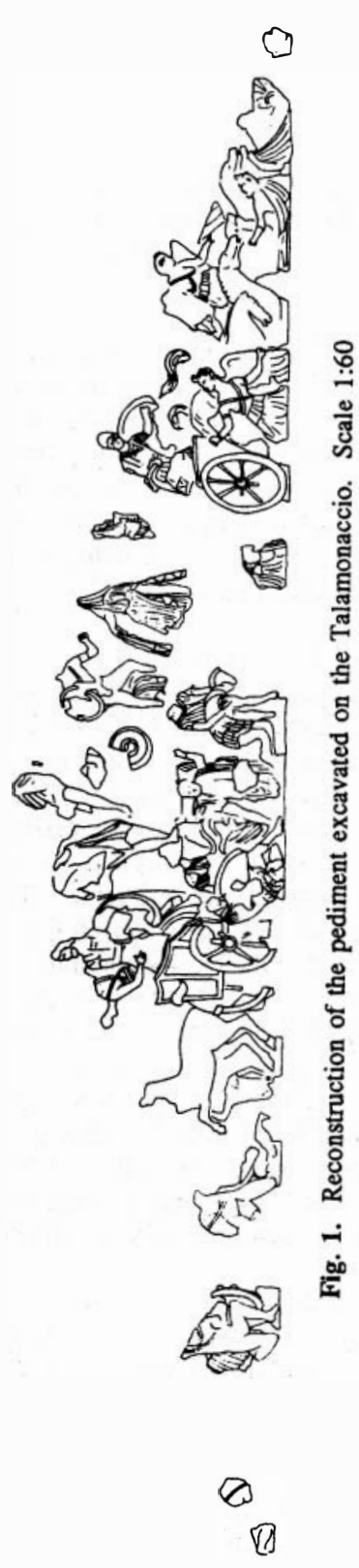

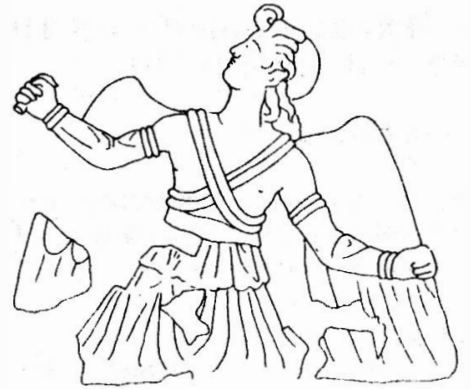

Fig. 2. Image of a vanth

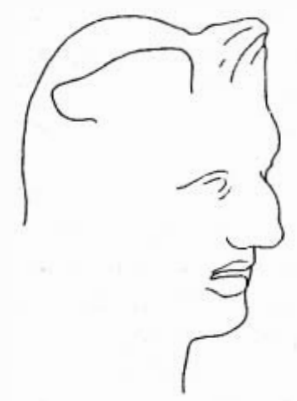

Fig. 3. Head of a Charun

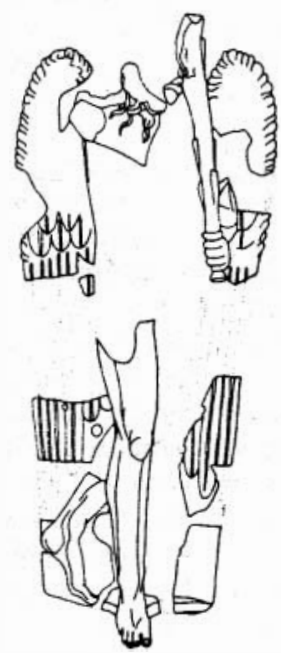

Fig. 4. Winged genius, probably from the porch to the cella. 
a funerary figurative language. Probably because of this and the description of the battle by the ancient sources two scholars associated these decorations with an allegory for memorial purposes.

According to Milani the depiction of the Seven against Thebes is an allegory of the battle against the Gauls. The fratricide of Eteocles and Polyneices, which he interpreted as the second pediment, was an allegory of the battle between Marius and Sulla (Milani,1912, 66ff.).

Von Vacano suggests the possibility that the decoration of the temple was ordered by the families of the two consuls who fought in the battle of 225 BC One of the consuls, C. Atilius Regulus, died during this battle, while his colleague, L. Aemilius Papus, left the battlefield as a victor after which the Senate awarded him a "Triumphus". According to Vacano the families of these consuls ordered the pediment as a memorial for the battle against the Gauls (Vacano 1975, 255). Both suggestions were barely documented. However the archaeological data and the funerary figurative language of this period allow a more detailed interpretation. Before discussing both hypotheses, the ancient literary sources will be studied in order to discover what they reveal about Telamon, the two families of the consuls and temple dedications.

\section{Ancient literary sources}

The battle near Telamon was described most extensively by Polybius, the Greek historiographer who belonged to the circle of Scipio Aemilianus. In Book 2, capita 23-31, he describes how the Romans, fearing a new fall of their city (the Gauls had sacked Rome in $387 \mathrm{BC}$ ), gathered a huge army to face the danger. The autonomous people of Italy were also anxious about a Gallic invasion and supported the Romans voluntarily. The first battle between the Gauls and the united people of Italy was won by the Gauls. In the meantime the army under the command of Consul Gaius Atilius landed on the coast near Pisa and advanced towards the enemy which was then caught between two Roman armies. At Telamon the decisive battle, in which Gaius Atilius died, was fought. His head was brought to the Gallic kings Concolitanus and Aneroëstes. The Gauls however were beaten by the Romans after a fierce battle in which 40.000 Gauls died and at least 10.000 , amongst them Concolitanus, were captured. Aneroëstes fled with some followers and later killed himself. The Roman consul Lucius Aemilius gathered the booty and sent it to Rome. With his legions he went through Liguria and invaded the land of the Boii, the ally of the Gauls. His men looted the country after which he returned in a few days to Rome. He sent the standard and the golden collars of the Gauls to Rome in order to decorate the Capitol and used the prisoners and the rest of the spoils of war for his entry into Rome during his Triumphus. In this way the Gauls, who had posed a very serious threat to the Italians and Romans by the invasion, were destroyed.

The battle has been discussed to a lesser extent by Pliny (N.H., III, 138), Diodorus Siculus (XXV, 13), Eutropius (III, 5) and Florus (I, 20). On the Lapidibus Capitolinis Barberiniis Telentinate it is written that Consul $\mathrm{L}$. Aemilius Papus held a Triumphus de Galleis on March 5, 225 BC (Corpus Inscriptionum Latinarum, 1891, 173). Polybius did not comment on the reactions of the Romans to the threat of the Gauls. Livy (59 BC-AD 17) on the other hand states that the Romans during a similar threat, the second Punic 
war (218-201 BC), dedicated many gifts and made a temple vow to the gods in order to assure their favour. Polybius does not mention this in his account of the second Punic war. Neither the dedication of a temple nor the erection of a monument is described by him. Thus the most important ancient literary source of the battle of Telamon does not give the information needed.

The gens (family) of the Aemilii belonged to the great Roman nobility. According to Plutarch (AD 46-120, II, 3), Aemilia, the daughter of Aeneas and Lavinia gave birth to Romulus. By tracing their ancestry back to the founders of Rome the Aemilii considered themselves one of the oldest noble families of Rome. The Atilii belonged to the great Campanian nobility. During the first reaty between Rome and Campania in $340 \mathrm{BC}$, the Campanian nobility received Roman civic rights assuring them the same privileges as the Roman patricians. Thus the Roman nobility assured itself a top layer of plebeians with whom they could enter into engagements. At a later date these Campanian families were elevated to the Roman nobility (Münzer 1920, 58).

Temple dedications and consecrations are often mentioned in ancient literary sources. The discussion of these dedications is of importance since they were partly used by the Roman noble families to commemorate their ancestors and their achievements. This seems particularly to be the case after the peace of Apameia in $188 \mathrm{BC}$ (Vacano 1975, 255). The dedications in which the Aemilii and Atilii were involved are especially mentioned below since this can shed light upon the origin of the decorations of the temple on the Talamonaccio. The combination of temple consecrations and ancestry worship has been attested and strengthens the suggestion of Vacano for the Talamonaccio temple. On June 3, 296 BC, Appius consecrated a temple to Bellona in which he placed images of his ancestors (Rohde 1963, 198). This indicates that temple dedications were used by the Roman nobility as propaganda to advance their family respectability. Another example is given by the Aemilii. In $179 \mathrm{BC}, \mathrm{M}$. Aemilius Lepidus made two temple vows, to Diana and Juno, during a battle against the Ligurians. This battle was not important and did not justify two temple vows which suggest propaganda motives (Rohde 1963, 198). Münzer (1920, 170) however, gives another version of the two temple vows. According to him L. Aemilius Regillus made a temple vow in $190 \mathrm{BC}$ after which he entered Rome in $189 \mathrm{BC}$ where he was granted a Triumphus. In $179 \mathrm{BC}$ this temple was consecrated by M. Aemilius Lepidus because L. Aemilius Regillus had died.

Florus (I, 14) mentions that M. Atilius Regulus made a temple vow to Pales during a battle near Brindisi against the Sallentini. This temple was consecrated on April 21, 267 BC (Wissowa 1902, 165). Another example is given by Livy in Book 23, capita 21 and 22. Marcus Atilius and Gaius Atilius, who were elected duumviri in $216 \mathrm{BC}$, consecrated a temple to Concordia,to whom Lucius Manlius, when he was praetor in $218 \mathrm{BC}$, made a vow (Broughton 1951, 238). He mentions that according to a bill of Marcus Minucius, the triumviri mensarii were appointed in order to decrease the deficit of money. These triumviri were Lucius Aemilius Papus, who had been consul and censor, who had been granted a Triumphus in 225 BC, Marcus Atilius, who had been consul twice, and Lucius Scribonius Libo, who had been tribune of the plebeians. Therefore the Aemilii and Atilii were connected, at least on a 
business level, after the battle against the Gauls in $225 \mathrm{BC}$, and could indeed have ordered the Talamonaccio pediment.

From the ancient literary sources two points in respect to temple vows and consecrations can be deduced. First that Polybius, from whom the information about the battle at Telamon in $225 \mathrm{BC}$ mainly derives, does not mention any temple vows. As a pragmatic historiographer he would not mention temple vows just as he omitted to comment on the reaction of the Romans on the threat of the Gauls. Secondly that individuals dedicated temples often partly in order to advance their families respectability. It is known that the Aemilii and Atilii were involved in temple consecrations at least four times in the third and second century $\mathrm{BC}$ However temple consecrations after a vow are only known for the city of Rome, where they would have had the most impact. This makes a consecration or decoration at Telamon hypothetical.

\section{Two hypotheses}

In 1888 Gamurrini situated the Etruscan town Telamon on the Talamonaccio after discoveries during the work on a new fortification system (Gamurrini, $682 \mathrm{ff}$ ). Vacano made some objections to this assignment and puts forward the ancient name Marta which has been documented since AD 765 (Vacano 1988, $1 \mathrm{ff}$ ). Both propositions remain tenable until further proof is found.

As a result of the discoveries during work on the fortification, the Talamonaccio was excavated more carefully in 1892 by Sordini under the supervision of L. Milani. This excavation remained unpublished and the excavation diary was lost until 1985 , when it was discovered in the State Archives of Spoleto (Sensi 1987). During the 1892 investigation the temple decoration of the Seven against Thebes was found. The terracotta fragments were discovered at the back of the temple and the position of the fallen pieces makes it possible to assign the decoration of the Seven against Thebes positively to the pediment at the back of the temple. Thus Amphiaraus' downfall to the underworld coincides with the sunset which corresponds to the Etruscan concept of the West as the region of the death and the gods and demons of the underworld (Vacano 1988, $31 \mathrm{ff}$ ).

According to Milani the temple, to which this pediment belonged, was dedicated to Jupiter. Two reconstructions were made after the 1892 excavation. One showed a fragmentary long central figure representing Jupiter, the escaping Adrastus and the downfall of Amphiaraus. Milani considered this reconstruction to be an allegory of the battle of $225 \mathrm{BC}$ Adrastus and Amphiaraus were interpreted as the two leaders of the fighting Gauls, Aneroëstes and Concolitanus, whose history shows similarities with the depicted heroes. The other pediment showed a battle in front of the Theban walls and the fratricide. This pediment was seen as an allegory of the battle between Marius and Sulla, dated 1st century BC (for illustrations of the old reconstructions see Tafel 7, 8 and 9, von Freytag gen. Löringhoff 1986). The pediment with Jupiter was dated by Milani to the beginning of the 2 nd. century BC Both pediments are however stylistically similar and cannot be dated separately. Thus the present day reconstruction by Vacano combines the two pediments (Fig. 1) and was presented to the public early in the 1970's. By 
accepting this new reconstruction as the pediment at the back of the temple, the allegory on Marius and Sulla, devised by Milani, is no longer tenable.

The allegory devised by Vacano is not tenable either, because families, if they did wish to advance their respectability, used more explicit references for their ancestors exploits. Depictions of the Seven against Thebes were too common in this period for such a purpose. About $20 \%$ of the 388 ums from Volterra, Chiusi and Perugia were classified as belonging to this theme (van der Meer 1978, 110). It is not explicit enough to contain references to the families of the consuls who fought against the Gauls at Telamon in 225 BC Neither the terracottas of the Seven against Thebes nor other archaeological finds from the Talamonaccio contain specific enough references to the exploits of the Aemilii and Atilii. An example of these references can be found in the temple of Bellona mentioned above. Appius consecrated this temple on June 3, $296 \mathrm{BC}$ and adomed it with images of his ancestors. Other examples of veneration of ancestors can be found on coins on which the mintmasters refer directly to their ancestors. Two silver coins which were respectively minted by the mintmasters C. Augurinus (133-126 BC) and his son, about 20 years later, show a reverse side with a monument to one of their ancestors, L. Municius Augurinus. This ancestor decreased the price of com in the late 5th century BC and a bronze column with his statue was erected to honour him. On the reverse of the two coins this monument was depicted, with on both sides L. Minucius Augurinus and M. Minucius Faesus, . Another silver coin was minted in $71 \mathrm{BC}$ by $\mathrm{P}$. Aemilius Lepidus. This coin commemorates the victory at Pydna in $168 \mathrm{BC}$ after which L. Aemilius Paulus returned to Rome with the Macedonian king Perseus and his sons as prisoners of war. P. Aemilius Paulus, a handcuffed Perseus with two sons and a trophy are depicted on the coin (Brilliant 1963, $38 \mathrm{ff}$.).

Another reason for not supporting Vacano's views is that for propaganda purposes it would be much more efficient for the families to erect a monument in Rome than on the Talamonaccio, especially when a triumph was commemorated. As mentioned before, consul L. Aemilius Papus went as a triumph through the streets of Rome March 5225 BC. During his triumphus the consul himself almost became a god. "Amidst cheers 'io triumphe' he entered the city through the Porta Triumphalis, while he stood on his chariot which was drawn by four horses. He was dressed in theomatis Jovis, or Jupiter's clothes, consisting of a purple toga and a tunic embroidered with palm motifs. He held a sceptre, which was crowned by an eagle in his hand and his face was painted red. It seemed as if Jupiter himself entered Rome" (Versnel 1970, 1; 56 ff.). For the Romans, a triumpher was a carrier of manna (the prosperity once embodied by the triumpher). By his entry he brought wealth and benediction to the city, as the Gods did (Liebeschuetz 1979, 39). During the funeral oration of a triumpher his "insignia triumphalis" were shown. A part of the body, the "os resectum", or cut off bone, was buried in the town where the family could erect a monument (Blümner 1911, 490). By burying a part of the body of a triumpher within the city walls, the Romans believed in keeping the manna within the city. Thus to propagate the share of the families in the achievement it would be much more effective for the Aemilii to erect a monument within Rome, where the "os resectum" was burried, than on the Talamonaccio. The erection of a monument on the 
Talamonaccio by the families of the two consuls in order to commemorate their actions on the battlefield does not seem likely.

\section{The temple and its symbols of death}

It is surprising that none of the authors writing about the Talamonaccio and its temple comment on the implications of the symbols of death with which this temple is adorned. Before examining these symbols of death, the temple and its cult will be discussed.

A review of the dating of the remains on the Talamonaccio is important since the dating has been used by different authors for the interpretation of the temple. Accurate dating however appears to be impossible. The oldest remains of the temple on the Talamonaccio indicate an origin in the late 4th, early 3rd century BC (Andrén 1940, 232 ff.). This is mainly based on the different types of revetment tiles found on the Talamonaccio (Vacano 1969, 675 ff.). The oldest antefixa, or ornamental tiles on cornices, were decorated with Satyrs and Menads and replaced by antefixa with Minerva and Heracles. The original sima (crowning moulding, originally the gutter, of a cornice) with palmettes was superseded succesively by lilies and roses, sea animals and, in the second quarter of the 2nd century BC, by tiles similar to the tiles used for temple D at Cosa (Brown et al. 1960, 166 ff.; Vacano 1985, 88). A date for the temple and the pediment can only be given with a margin since an exact dating of the tiles is controversial.

Unlike Brown and Vacano, Andrén (1940,232 ff.) does not date the revetment tiles succesively but all together in the 3rd century BC The old temple was redecorated in the 2nd century BC Part of the redecoration was the pediment with the Seven against Thebes. The date of the pediment ranges from the late 3rd to the late 2nd century BC (Libertini 1921, 137 ff.; Andrén 1940, 227 ff.). After a detailed study von Freytag dates the pediment in the second quarter of the 2 nd century BC, based on the depicted antiquaria and by analogy with temple D in Cosa (von Freytag, gen. Löringhoff 1986, 223 ff.). This date however is an approximation and accurate dating of the pediment is impossible, since none of the monuments from the late 3rd century BC until the late Republican period is dated accurately. Dating by style and revetment tiles is not sufficient for this period.

The temple itself was reconsiructed by Vacano after his excavations in in the 1960's. Although excavation material was scanty, he reconstructed a tetrastyle temple (12,9 m wide and 19,4 m long), a cella with two alae, stairs and an area sacra. The measurements of the pediment were thought to be $8.8 \mathrm{~m}$ long and $1.5 \mathrm{~m}$ high (Vacano 1969, 1975). More recently Vacano has adjusted his view about the redecoration. He considers the temple no longer redecorated but newly built with the sporadic use of the quality materials of its predecessor. The cella did not reveal any older materials at all and must have been newly erected (Vacano 1988, 31).

The archaeological material from the Talamonaccio can not be interpreted plainly due to the almost continuous occupation of the hill and its excavation history. This leaves enough space for conjectures like the one of the cult performed in and around the temple. Though there are no indications of a cult before the pediment adorned the temple and while no votive deposits and inscriptions were found, scholars dedicated the temple to a variety of 
gods. The antefixa of Satyrs and Menads indicate a Dionysian cult and due to antefixa and some terracotta fragments of Heracles, this hero-god would have had his own cult on the Talamonaccio. A terracotta statue of a crowned, bearded, elderly man demonstrates a Tinia/Giove cult and some statucttes of a female goddess, spindle whorls and loomweights indicate a cult dedicated to a goddess such as Uni/Guinone (Vacano 1985, $128 \mathrm{ff}$.). Faced with so few objects and indications and so many different gods the only conclusion can be that the cult practised on the Talamonaccio is unclear (Freytag, gen. Löringhoff 1986, 27). Therefore the author would rather speak of a building with characteristics of a temple than of a temple.

The symbols that point to a function of this building indicate a funerary meaning. Both Milani and Vacano must have sensed this on account of their devised allegories but neither attempted to investigate all the indications.

The depiction of the Greek myth of the Seven against Thebes on the pediment at the back of an Etruscan building is of importance for its funerary character. From an early date the Etruscans knew the Greek myths thoroughly (Hampe \& Simon 1964, $18 \mathrm{ff}$.). During the 5th century BC they developed a preference for certain Greek mythological themes like the Seven against Thebes and the death of Capaneus and Tydeus. In the 4th and 3rd century BC the fratricide of Eteocles and Polyneices was added to these themes. It is conspicuous that the Seven against Thebes themes usually were depicted on objects concerned with death. Thus the Seven against Thebes and the fratricide were often used as a theme on sarcophagi and cinerary ums in the 3rd and 2 nd century BC As mentioned before about $20 \%$ of the 388 urns from Volterra, Chiusi and Perugia were classified as belonging to the Seven against Thebes theme, which is the second theme on cinerary urns (van der Meer $1978,110 \mathrm{ff}$.). The funerary character of the pediment is however established by the occurence of at least 5 underworld figures, female and male.

Pfiffig distinguishes 3 types of underworld demons: one female, the Vanth type, and 2 males, Tuchulcha and Charun (Pfiffig 1975, $323 \mathrm{ff}$.). The Vanth, Etruscan underworld demons, wears a skirt with a belt and two strings crossing each other at the breast. She has wings and carries torches, snakes or a short sword (Fig. 2). Three Vanths are depicted on the pediment. The fourth female, a winged, torch bearing figure, does not conform to the description but since the torch is an attribute of female underworld beings, she belongs to the female underworld demons (Freytag, gen. Löringhoff 1986, $159 \mathrm{ff}$.). On the Talamonaccio more fragments of another head of an underworld demon and torches were excavated. These could not be included in the reconstruction and record the presence of more underworld demons. The fifth underworld figure on the pediment was identified by Vacano as the male Charun, pulling the horses of Amphiaraos' chariot into the underworld. Charu, or Charun, is a male underworld demon with a deformed face and a hooked nose. He usually wears a costume and a hammer thrown over his shoulder. Sometimes he is depicted with wings. During the hellenistic period his face seems to become more normal, though he keeps a hooked nose. Small wings appear on his head at the temple (Fig. 3). Von Freytag has doubts whether this figure can be identified as Charun though she still considers him as the team conductor to 
the underworld, and to belong to the underworld demons (Freytag gen. Löringhoff 1986, $114 \mathrm{ff}$.).

The last association with death and the underworld in the pediment is the direction into which Amphiaraus vanishes into the underworld. As it has been established that the pediment decorated the back of the building, Amphiaraus' downfall coincides with the sunset, corresponding to the concept of the West as the realm of death (Vacano, 1988, 38).

The pediment at the front of the building might also have a theme associated with funerary practices. Two fragments of sea monsters, symbolising the journey to the realm of death, are positively allocated to the pediment at the front (Vacano 1988, $39 \mathrm{ff}$.). The Etruscans believed in a journey over the sea to reach the green island, the Elysium, in the far West. To the symbolic depictions of this journey belong the sea monsters, hippocampi, dolphins and wavy lines, depicted in tombs and on cinerary urns as in the Tomba delle Leonesse in Tarquinia (Pfiffig 1975, $168 \mathrm{ff}$.). The many fragments of sea monsters, hippocampi and snakes excavated on the Talamonaccio by Sordini in 1892 should be interpreted as belonging to these funerary symbols. The head of a griffin, for example, could very well belong to an excavated body of a sea monster since sea monsters with griffin heads are often encountered on objects symbolising the journey to the far West. Another fragment that could belong to the pediment at the front is a female upper body with breasts (Vacano 1988, 41).

Two nearly life size winged genii (fig.4) in high relief have bicn located by Vacano on both sides of the porch to the cella (Vacano 1985, 90 ff.). The genii are very fragmentary and are interpreted as winged youths. One of them can be reconstructed as being in action, with a stick held in his left hand resting on his shoulder. Though the upper part of the stick is missing, Vacano interprets it as a pedum, a crook, and the genius as a Genius of Season. The possibility that the stick is part of a torch should not be dismissed. Vacano's first impression was that the winged genii were pendants as in the Tarquinia tombs and on sarcophagi. This impression seems more valid than the interpretation of Genius of Season. Erotes as naked youths with wings and torches are known as pendants, like that on an urn from the Tomba del Granducca in Chiusi. This demonstrates that naked winged youths do belong to the repertoire of funerary symbols (B-K 3, CXXXIX, 5; for other hellenistic urns with winged youths see Urne Volterrane 1, 1975, no. 96 and Ume Volterrane 2, 1977, nos. 50, 52 and 54).

More direct indications that the building on the Talamonaccio is a funerary monument are not available. However the building has a temple character as well. This is not a contradiction since funerary monuments imitating temples, such as the 4th century BC tombs with temple facades in Norchia and the temple-like 2nd century BC tomba Ildebranda in Sovana (ca. $10 \times 12 \mathrm{~m}$ ), were familiar to the Etruscans suggesting that buildings with a seemingly religious function were also used for other purposes. Apparently death and religion are closely connected in Etruria and cannot be separated automatically.

The funerary monument on the Talamonaccio might have been erected in honour of fallen soldiers. Soldiers were cremated or buried collectively near the battlefield (Toynbee 1971, 55). Many weapons were excavated on the 
Talamonaccio. The deposit of miniature weapons, called the Ripostiglio del Genio Militare, do not count as indications, since the contents of the deposit are too mixed. Nevertheless the excavations yielded about 60 pila (Roman javelins or spears of about $2 \mathrm{~m}$ length) probably used in a battle, due to their distorted heads (Vacano 1988, 48 ff.). The pilum is a typical Roman weapon used much in the 2nd century BC Polybius mentions that the use of the pilum was decisive for the battle near Talamone in $225 \mathrm{BC}$ (II, 20). Yet the Talamonaccio pila can not be attributed to the battle against the Gauls without further research, since their dating ranges from the 3rd to the 1st century BC

Between 1887 and 1892 many more iron weapons were found but due to their bad state of preservation these cannot be studied. Sordini for example describes on May 30 and 31, 1892 a layer of iron objects at the depth of two metres on the East side of the temple. This layer consists of lances, scabbards, sheets of iron and swords (Sensi 1987, 60). The terracottas found with the iron, such as a tegula (roofing tile) with two palmettes painted in red and black with a white background, indicate a dating of the iron layer similar to the date of the temple.

The combination of the iron weapons, the funerary character of the decoration of the building and the need of a distinct cult suggests that the building on the Talamonaccio is a funerary monument erected in honour of the fallen soldiers. To the author's knowledge these monuments are not attested for in Italy. War monuments are known in Greece as the polyandria erected by several city states commemorating their fallen soldiers. Tanagra for example burried its own dead, who fell at Delion (424 BC), in a polyandrion. An inscription discovered near Tanagra shows that the State carried out the burial and marked the mass grave with a monument carrying the names of the Tanagrans who died at Delion (Schilardi 1977, 22).

While the date of the funerary monument on the Talamonaccio cannot be given it remains unclear in which battle the commemorated soldiers fell since the area around Talamone was a fierce battlefield in the 3rd and 2nd centuries BC There are however indications in the ancient texts and the pila that it might have been the battle against the Gauls in 225 BC

\section{Conclusions}

The reconstructed pediment of the Seven against Thebes contains many references to funerary figurative language. The theme of the Seven against Thebes itself belongs to this language since it is one of the more important themes on sarcophagi and cinerary urns. Direct references to the realm of death within the pediment are the many representations of death demons like the Vanth and Charun and the actual direction of the vanishing Amphiaraus. These indications, combined with the knowledge of ancient literary sources, probably gave birth to the allegories devised by Milani and Vacano. According to Milani who reconstructed two pediments, the Seven against Thebes is an allegory of the battle against the Gauls at Telamon in $225 \mathrm{BC}$ The fratricide of Eteocles and Polyneices, which he interpreted as the second pediment, was an allegory of the battle between Marius and Sulla. By accepting the new reconstruction of Vacano as the pediment at the back of the building on the Talamonaccio, the explanation for the fratricide is no longer tenable. The allegory of Vacano, who interpreted the two consuls fighting at 
Telamon in $225 \mathrm{BC}$ as Adrastus and Amphiaraus, is not tenable either. Vacano suggests that the two families of the consuls ordered the redecoration of the temple.

In favour of this view is the knowledge that Roman noble families often dedicated temples partly to advance their respectability. Additionally the two families of the consuls were connected on a business level after the battle against the Gauls in 225 BC However Roman families used more explicit references if they wished to advance their respectability than those found on the Talamonaccio. It cannot be deduced from the archaeological evidence that the families were involved in the decoration of the building. In addition it would be much more effective for the Aemilii and Atilii to erect a monument in Rome if they had wanted to increase their respectability by depicting their ancestor's deeds.

The allegories are not convincing. The amount of artefacts of funerary character, excavated on the Talamonaccio, is however considerable. Apart from the references on the pediment at the back of the building there are other indications of the building's funerary character such as the sea monsters on the pediment at the front and the two winged genii allocated to both sides of the porch to the cella. Since there is no evidence for a specific allegorical explanation for the building, another explanation, based on the archaeological artefacts, is introduced. The author proposes that the building on the Talamonaccio was partly erected as a funerary monument. The direct references to funerary symbols, in combination with the vast amount of weapons and the need for a distinct cult does suggest that the building on the Talamonaccio was a funerary monument erected in honour of fallen soldiers. Whether this monument was built to commemorate a specific battle or on account of a more general principle will remain unknown until the dating of the artefacts from the Talamonaccio can be established.

\section{Glossary}

Ala(ae): outer passage(s) flanking the side walls of the cella on an Etruscan temple.

Antiquaria: objects from antiquity.

Area sacra: open-space lobby.

Cella: central chamber, or sanctuary, of a temple.

Duumviri: commision consisting of two men for variousassignments.

Praetor: civil servant responsible for civil law and enforcement of private law.

Triumviri: board of three men responsible for banking.

\section{References}

Andrèn, A. 1940. Architectural Terracottas. Rome: Svenska Institutet i Rom. Blümner, H. 1911. Die rîmische Privataltertümer. München: Beck, 474-512.

Brilliant, R. 1963. Gesture and Rank in Roman Art., Memoirs of the Connecticut Academy of Arts and Sciences, February. Volume XIV.

Broughton, T.R.S. 1951. The Magistrates of the Roman Republic 509-31 $B C$, Volume I. New York: American Philological Association.

Brown, F.E., Richardson, E.H., \& Richardson, L. jr. 1960. Cosa II, the Temples of the Arx. Memoirs of the American Academy in Rome. 
Brunn, H. \& Körte, G. 1916. I rilievi delle urne Etrusche III. Vereinigg. wiss. Verleger in Komm., Rome and Berlin.

Cristofani, M. 1975. Urne Volterrane I. I complessi Tombali. Corpus delle urne etrusche di età ellenistica I . Firenze: Centro Di.

Cristofani, M. 1977. Urne Volterrane II. Il Museo Guarnacci Parte Prima. Corpus delle urne Etrusche di età ellenistica. Firenze: Centro Di.

Dressel. 1891. Corpus Inscriptionum Latinarum. Berolini: Consilio et Auctoritate Academiae Litterarum Borussicae.

Freytag von gen. Löringhoff, B. 1986. Das Giebelrelief von Telamon. Mainz: Verlag Philipp von Zabern.

Gamurrini, G.F. 1888. Ruderi Antichi ed oggetti scoperti sul Poggio di Talamonaccio. Notizie degli Scavi, 682-691.

Hampe, R. \& Simon, E. 1964. Griechische Sagen in der frühen etruskischen Kunst. Mainz: Verlag Philipp von Zabern.

Krauskopf, I. 1974. Der thebanischen Sagenkreis und andere griechische Sagen in der etruskischen Kunst . Mainz: Verlag Philipp von Zabern.

Libertini. 1921. Dissertationi Pontifica Accademia, 15: 137 ff.

Liebeschuetz, J.H.W.G. 1979. Continuity and Change in Roman Religion. Oxford: Clarendon Press.

Meer, van der L. 1978. Etruscan Urns from Volterra. Meppel.

Milani, L.A. 1912. Il R. Museo Archeologico di Firenze. Vols. I \& II. Firenze.

Münzer, F. 1920. Römische Adelsparteien und Adelsfamilien. Stuttgart: Metzler.

Pfiffig, A.J. 1975. Religio Etrusca. Graz: Akademische Drucku.Verlagsanstalt.

Rohde, G. 1963. Die bedeutung der Tempelgrundungen im Staatlebender Römer. Studien und Interpretationen zur Antiken Literatur ,Religion und Geschichte. Berlin: 189-206.

Schilardi, D.U. 1977. The Thespian Polyandrion (424 B.C.). The excavation and finds from the Thespian State Burial. Vol. I. Ann Arbor Michigan: Xeros University Microfilms.

Sensi, L. 1987. Gli scavi di G. Sordini sul Poggio di Talamonaccio (20.4.4.6., 1892). Biblioteca di "Studi Etruschi", 15. Firenze: Leo S. Olschki Editore.

Toynbee, J.M.C. 1971. Death and Burial in the Roman World.. London: Thames \& Hudson.

Vacano, von O.W. 1969. Zum Grundriss des Tempels auf den Talamonaccio. Hommages à Marcel Renard III. Bibauw, J. (ed.). Bruxelles: Collection Latomus.

Vacano, von O.W. 1975. Der Tempelgiebel von Telamon. Mitteilungen des Deutschen Archaerlngischen Instituts Römische Abteilung 82.

Vacano, von O.W. 1985. vili Etruschi a Talamone. Bologna: Cappelli editore.

Vacano, von O.W. 1988Etruschi", 17. Firenze: Leo S. Olschki Editore.

Versnel, H.S. 1970. Triumphus, an inquiry into the origin, development and meaning of the Roman Triumph. Leiden: Brill.

Wissowa, G. 1902. Religion und Kultus der Römer. München: Beck. 